\section{Use of growth hormones}

SIR-So far as I know, there are no regulations as yet that "prohibit the use of bovine growth hormones in the fattening of cattle" (Nature 338, 281; 1989). Unless there is recent new legislation, of which I am unaware, your well-motivated leading article is ambiguous. I suspect that all your references to "bovine growth hormone" should be replaced by "anabolic steroids", a totally different group of hormones. This suspicion is based on my knowledge of the European regulations on the use of "growth hormone", which I have been informed is as follows:

(1) Council Directive $81 / 602 / \mathrm{EEC}$ prohibits the use in the Community of steroids (having androgenic, oestrogenic, gestagenic or thyrostatic activity) in foodproducing animals and was implemented on 1 January 1988. The United Kingdom introduced the legislation on 1 January 1987 because the steroid products licensed at that time had recommended withholding times of one year.

(2) The Happart report (Hormones and the BST hormone in the dairy and meat industry) was debated by the European Parliament on 5 July 1988. This called on the European Commission to conduct a wide-ranging inquiry into various implications of the introduction of bovine somatotropin (BST) into the Community. Notably, an amendment calling for a ban on BST in the Community was voted on separately and rejected by the parliament. (3) On 16 September 1988, the European Parliament debated and passed a resolution on the use "of hormones in meat production". This was concerned almost entirely with the use of steroids (referred to simply as "hormones") in livestock fattening. However, one of the 13 resolutions approved by the parliament calls for "support for a world-wide ban on the use of hormones and other substances to improve productivity in livestock production and support for a world-wide ban on the production, marketing and use of hormone produced through genetic engineering aids for fattening and substances used to increase productivity in animal production as part of the current round of GATT negotiations". Of a total of 518 European MPs, only 114 (22 per cent) voted. A resolution by the European Parliament is only an expression of opinion. European law is set by the Council of Ministers, who have only enacted the original steroid ban legislation.

A further recent development which has presumably prompted your article is the publication on 21 March 1989 of a report by the European Parliament's committee of inquiry into "the problem of quality in the meat sector". This will go to the parliament's plenary session on 10 April. The committee comprised 15
MEPs and was chaired by Carlos Pimenta (Portugal). This report supports the existing steroid ban and calls for tightening of enforcing procedures for consumer safety reasons (against the best scientific advice). The committee also stated that it is "opposed to the registration of new genetically engineered growth hormones and recommends the setting-up of a permanent scientific programme to look into the questions raised by the ever-increasing use of high technology in the production of food". This report was supported by nine of the 15 members. Five members dissented and felt strongly enough to produce their own minority report which supported the scientific evidence that the five licensed (steroid) hormones were "indisputably safe" and called for the commission to reconsider the ban.

Institute of Animal Physiology and R. B. HEAP

Genetics Research,

\section{Babraham Hall,}

Cambridge CB2 4AT, UK

SIR-I believe most scientists involved in assessing the safety, quality and efficacy of medicinal products or the potential application of new biotechnological techniques in farm animal production will applaud the reference in your leading article "More wicked ways with hormones" to an "intellectual millstone" for the EEC if the European Parliament accepts the recommendations of its committee of inquiry into the problem of quality in the meat sector (European Parliament PE 130073/A/Fin, 21 March 1989) and advises the EEC to continue the 1988 hormone ban.

Unfortunately, your article contains an error concerning the current situation in that the 1988 directive $(88 / 146 / \mathrm{EEC})$ bans the use of anabolic-type hormonal substances (including progesterone, testosterone, oestradiol- $17 \beta$, trenbolone and zeranol, previously licensed in the United Kingdom under the Medicines Act) but does not include 'growth hormone' preparations, that is, the somatotrophins. The $\beta$-agonists and recombinant growth hormone preparations are under consideration in some EEC countries but have not, as far as I am aware, been evaluated by the relevant EEC committees. However, in a closely argued minority report (CS/CCG/RAP/406) supported by a group of British MEPs and Professor Raftery of Ireland, which recommends the removal of the hormone ban, they cite that Commission staff confirmed that (1) they had no evidence of harm to animal or human, and (2) the ban was introduced for a mixture of political and commercial reasons, not to protect the consumer. It is to be hoped that both reports will be examined carefully by MEPs, thus preventing a recurrence of the 1985 vote, when only 127 MEPs out of some 450 voted, and few (about 45) attended the debate.

However, there is also a disturbing new draft report to the European Parliament by the Committee on the Environment, Public Health and Consumer Protection (Doc B2 434/87 - rapporteur: Mr Ken Collins) which, in para 13 , "recommends, as part of the current round of GATT negotiations, a world-wide ban on the use of hormones and other substances used to improve productivity in livestock production and support for a world-wide ban on the production, marketing and use of hormones produced through genetic engineering, aids for fattening and substances used to increase productivity in animal production".

The current trade difficulties between the EEC and the United States, the increased incidence of use of previously banned dangerous anabolic agents, and problems with monitoring and policing the current hormone ban all stem from a previous 1985 report which led to the imposition of the current hormone ban. There is indeed, a bleak future for the development of human and veterinary drugs if the European Parliament similarly accepts this proposal, not least because research and development of both are inextricably interlinked.

G. E. LAMMING

University of Nottingham,

Department of Physiology and

Environmental Science,

Sutton Bonington,

Loughborough LE12 5RD, UK

\section{Earthquake risk}

SIR-The disastrous earthquake in Armenia (Nature 337, 107; 1989) drew attention to the study of the seismic risk of nuclear power plants. In the Soviet Union, Mikhail Gorbachev proposed an international examination of some sites.

As a seismologist, I took part in seismic risk estimation for nuclear power plants in Hungary (Paksh, 1987) and Czechoslovakia (Bogunichich, 1988). The results of the research are not classified secret, but they have not been published anywhere. Publishing rights are reserved by the governments of the respective countries.

I would like to draw attention to this problem. I believe that publication of our results, international examination of seismic risk at both sites and subsequent reinforcement of these plants (closing them if necessary) should happen as soon as possible.

M. SALGANIK

Institute of Physics of the Earth,

Laboratory of Strong Ground Motion Prediction.

Moscow 123810, USSR 